\section{Greenwich 'could be symbolic timekeeper for electronic era'}

London

Britain is bidding to make the Royal Observatory at Greenwich the symbolic timekeeper of the Internet by launching Greenwich Electronic Time (GeT).

The bid is being led by a consortium of more than 4,000 European online retailers from 20 countries, known as the Interactive Media in Retail Group (IMRG). IMRG hopes that GeT will become the standard time for all electronic commerce.

Consortium officials also say that GeT would smooth the path of electronic transactions on the Internet; at present, they argue, a lack of standardization in e-commerce means that goods can be owned by two parties at the same time.

Despite its name, $\mathrm{GeT}$ is not Greenwich Mean Time: it is another way of describing Co-ordinated Universal Time (UTC). Based on an agreement by more than 200 countries with atomic timekeeping, UTC uses an average of the time as measured by atomic clocks in these countries. It is so accurate that it occasionally needs to be adjusted with 'leap seconds' to match the slightly irregular rotation of the Earth.

UTC is already used worldwide, and is popular among the commercial and scientific sectors in the US. But although available on the Internet, its existence is not widely recognized.

"For me the benefit of the GeT project is the publicity and marketing, establishing that this is the time standard on which we need to operate on the Internet," says John Laverty, head of the time section at the UK National Physical Laboratory in Teddington. He says there is "a lot of ignorance about what time standards are", and hopes GeT will raise awareness of time "etiquette".

Laverty has been advising IMRG about the new project. He says one of the reasons he is open to the idea is because of Swiss watchmaker Swatch's recent introduction of Biel Mean Time, which measures a day as 1,000 'beats' and created a new meridian in Switzerland.

"They've taken the start of the universal day as Central European Time," says Laverty. "This is convenient for Swatch headquarters, but if you are somewhere else in the world, dealing with Global Positioning System and UTC technology and your day starts at a different time, this is crazy."

Details of the proposal for GeT can be found at: www.get-time.org. Natasha Loder

\title{
Brussels research chief backs European website proposal
}

\section{Paris}

European Union research commissioner Philippe Busquin is backing plans by the European Molecular Biology Organization (EMBO) to establish a website called 'EBiosci'. This will be a European counterpart to PubMed Central, the free website for lifescience papers to be launched this month by the US National Institutes of Health.

E-Biosci has Busquin's "full support”, he told Nature this week. "It may have important implications, not only for the way scientific information is spread and accessed worldwide, but also for the way business will be run in this sector in the near future," he said.

An official from the European Commission's research directorate says the EC is open to paying part of the scheme's estimated US $\$ 3$ million annual running costs. Although EMBO has agreed to pay 500,000 Euros $(\$ 511,000)$ to start E-Biosci, the project has no firm plans as yet for long-term funding.

The commission will be represented next week at a meeting convened by EMBO in a bid to take E-Biosci forward. Representatives of European research councils and the Wellcome Trust will also attend, along with major publishers including Nature, Oxford University Press and Elsevier Science.

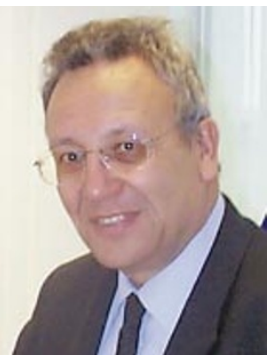

Busquin: encouraging E-BioSci partnership.
EMBO has until now been the driving force behind E-Biosci. The meeting aims to promote wider involvement, to reach agreement on the structure of E-Biosci and to seek commitments from public research funders.

"The project's success will require a true partnership between all the actors concerned and I would be ready to give my full backing to such a partnership," says Busquin.

The commission official says he hopes the meeting will result in the creation of a consortium to finalize and run E-Biosci, adding that such a consortium would be eligible for EU funding. "It is important that we have a credible alternative to PubMed Central, as without this we will be in a weak position to negotiate with the United States."

The sum required to run E-Biosci is relatively small, he points out, and the commission is allowed to fund such ventures under 'accompanying measures' to the Framework research programme.

Declan Butler

\section{Japanese support biotech start-ups}

Tokyo

The Japan Development Bank last week announced that it is to set up a dedicated biotechnology fund. The move reflects the growing willingness of Japanese investors to nurture domestic start-up companies.

Biotechnology-related investments by Japanese venture capitalists have tended to focus on established companies or foreign start-ups. In contrast, the new BioIncubation Fund will target domestic companies early in their development.

More Japanese scientists want to become entrepreneurs, following the announcement of new regulations for technology transfer from universities and government laboratories. There has also been a surge in public support for technology-based businesses.

About 20 biotechnology companies are believed to have been set up in Japan during the past year. But Japanese venture capitalists, many linked to large banks or security houses, have been slow to invest in start-ups.

"The increase in the number of newly established companies is very significant," says Robert Kneller, a professor in the department of intellectual property at Tokyo University's Research Center for Advanced Science and Technology.

Akiko Itai left the University of Tokyo five years ago to set up the Institute of Medicinal Molecule Design, a company developing software tools for drug design. "Many young graduates still prefer the security of a position with a large pharmaceutical company or a national university to working on an annual contract for a venture business," he says. Recruiting researchers from large companies is not an option, says Itai, because venture businesses can rarely match their salaries.

Biotechnology is not the only field to profit from the surge in venture capital. With a Japanese branch of the Nasdaq shares index opening its doors next summer, large companies and financial institutions are rushing to invest in technology-based companies.

Only about a third of the biotech companies set up last year originated in academia or government laboratories. This suggests that, in Japan, corporations may be a better source of entrepreneurial talent than universities for some time to come. 